\title{
The Nephroprotective And Antioxidant Activity of Sterculia rubiginosa Zoll. Ex Miq. Leaves
}

\author{
Rini Prastiwi ${ }^{1, *}$, Ema Dewanti ${ }^{1}$, Inka Nurul Fadliani ${ }^{2}$, Nessa Aqilla ${ }^{2}$, Salwaa Salsabila ${ }^{2}$, Vera Ladeska ${ }^{1}$
}

Rini Prastiwi ${ }^{1}{ }^{*}$, Ema Dewanti ${ }^{1}$, Inka Nurul Fadliani ${ }^{2}$, Nessa Aqilla², Salwaa Salsabila², Vera Ladeska $^{1}$

'Department of Pharmacognosy and Phytochemistry, Faculty of Pharmacy Universitas Muhammadiyah prof. Dr. HAMKA, INDONESIA.

${ }^{2}$ Department of Pharmacology, Faculty of Pharmacy Universitas Muhammadiyah prof. Dr. HAMKA, INDONESIA.

\section{Correspondence}

\section{Rini Prastiwi}

Department of Pharmacognosy and Phytochemistry, Faculty of Pharmacy Universitas Muhammadiyah prof. Dr. HAMKA, INDONESIA.

E-mail: khanzapras@gmail.com

History

- Submission Date: 09-01-2020;

- Review completed: 22-01-2020;

- Accepted Date: 17-02-2020.

DOI : 10.5530/pj.2020.12.121

Article Available online http://www.phcogj.com/v12/i4

\section{Copyright}

(C) 2020 Phcogi.Com. This is an openaccess article distributed under the terms of the Creative Commons Attribution 4.0 International license.

\section{ABSTRACT}

Background: Sterculia has an antioxidant activity. The Sterculia genus has phenols and flavonoids content, and this chemical content may be have an nephroprotective activity. Objective: The study was to investigate the in vitro study of antioxidant activity with DPPH and FRAP study and nephroprotective activity of Sterculia rubiginosa Zoll. Ex Miq. Leaves extract. Materials and Methods: The leaves was extracted using ethanol. This extract was determined for antioxidant activity by in vitro study with DPPH and FRAP methods, determined the content of total phenols, total flavonoids, and also identification of chemical content. Nephrotoxicity study done by induced gentamycin. The groups divided 6 group, consist: negative control, positive control, normal control, and the extract with dose $50 \mathrm{mg} / \mathrm{kg}, 100 \mathrm{mg} / \mathrm{kg}$, and $200 \mathrm{mg} /$ $\mathrm{kg}$. The parameter for nephroprotective activity was tubular necrosis, the presence of tubules casts and glomerular damage, creatinine serum, and urea. Results: The ethanol extract has $\mathrm{IC}_{50} 162.34 \mathrm{\mu g} / \mathrm{ml}$ for DPPH scavenging activity and $18.65 \pm 3.53 \mathrm{FeEAC}$ (Mol/g) for FRAP. The secondary metabolite presence flavonoids, tannins, terpenes, alkaloids, and glycosides. The total phenols $462.36 \pm 9.23 \mathrm{mg} \mathrm{GAE} / \mathrm{gr}$, total flavonoids content $59.44 \pm 0.11 \mathrm{mg} \mathrm{QE} / \mathrm{gr}$ extract. All the dose have an nephroprotective activity, but the best dose was $50 \mathrm{mg} / \mathrm{kg}$. Conclusion: The ethanol extract of Sterculia rubiginosa showed antioxidant activity and nephroprotective activity.

Key words: Sterculia rubiginosa Zoll Ex. Miq., Antioxidant, Nephroprotective, Gentamicin.

\section{INTRODUCTION}

The kidneys have important functions including removing waste products from the blood and regulating water fluid levels. Nephropathy is a health problem in the world. Long-term use of drugs, such as analgesics or chemotherapy, and degenerative diseases such as diabetes mellitus and hypertension are the cause of nephropathy. Several studies have reported that some natural compound compounds such as phenol, karetenoid, polysaccharide have an effect on inhibiting reactive oxygen species (ROS), which ROS will cause pathological conditions in organs, one of which is kidney. ${ }^{1}$ Gentamicin is an aminoglycoside antibiotic that is widely used in negative bacterial infections. Gentamicin is excreted by the kidneys and partly reabsorbed. And accumulated in the proximal membrane, which is a major part of nephrotoxicity. So that the possibility of nephrotoxicity becomes a risk in the treatment using gentamicin. ${ }^{2}$

Sterculia genus contains phenol compounds, flavonoids and their derivatives, terpenoids which are mostly as triterpenoids, coumarin, alkaloids and other compounds including phenolic acids, phenyl propanoids, fatty acids, sugars and some steroids. ${ }^{3}$ Based on literature studies it is known that the primary production of secondary metabolites in the genus Sterculia is phenols and flavonoids. Sterculia rubiginosa Zoll. Ex Miq. is one of the plants of the genus Sterculia. This plant has been used by people in West Java, Indonesia for the treatment of asthma. Some Sterculia genus plants have activities. Sterculia foetida for antibacterial and hemolytic, ${ }^{4}$ apoptosis. ${ }^{5}$, Sterculia diversifolia for immunomodulatory and anti-cancer. ${ }^{6}$ Sterculia villosa as fibrinolytic, ${ }^{7}$ sedative. ${ }^{8}$ Sterculia tragacantha as anti-inflammatory and analgesic. ${ }^{9}$ So it is interesting to study whether Sterculia rubiginosa has antioxidant and nephroprotector activity.

\section{MATERIALS AND METHODS}

\section{Materials}

Sterculia rubiginosa leaves woods collected from Botanical Garden of Bogor. This plant was determined in Botany Herbarium Research Institute, Cibinong, West Java, Indonesia. Ethanol from local supplier. Kit for urea from Sigma (Singapore). TPTZ (: 2,4,6-tripyridyl-s-triazine), Dimethyl sulfoxide (DMSO), methanol pro analysis, ethyl acetate pro-analysis, n-hexane pro analysis from Merck (Germany). Gentamycin from local supplier. Some chemical reagent for identification of the compound and determined the content of total flavonoids, total phenols and antioxidant activity by DPPH (2,2-Diphenyl-1-picrylhydrazyl) method.

\section{Extraction}

The extraction was done by maceration method using ethanol solvent. Extraction done with 200 gram of leaves powder with solvent. The extract was dried with a vacuum of rotary evaporator at temperature of $50{ }^{\circ} \mathrm{C}$ and then continued in water bath at $50{ }^{\circ} \mathrm{C}$. 


\section{The antioxidant activity with DPPH}

The extracts $(20 \mu \mathrm{g} / \mathrm{ml})$ of sample in methanol reacted with $180 \mathrm{ml}$ of $150 \mu \mathrm{mol} / 1 \mathrm{DPPH}$ (2,2-diphenyl-1- picrylhydrazyl) in methanol solution at room temperature. For a control, methanol used to replace the sample. The incubated at room temperature for $40 \mathrm{~min}$ in the dark place. The absorbance measured at $517 \mathrm{~nm}$. The positive control was quercetine. The antioxidant capacity was calculated using the following:

Antioxidant Activity (\%)= Absorbance control -Absorbance sample $\times 100 \%$ Absorbance control

The procedure, according to Bobo Garcia. ${ }^{10}$

\section{The antioxidant activity with FRAP}

The antioxidant activity test using the FRAP method. Thirty (30) $\mu \mathrm{l}$ samples put into the well. The sample dissolved in methanol. Then added $270 \mu \mathrm{L}$ FRAP reagents. The FRAP reagent was consist of Buffer: TPTZ: $\mathrm{FeCl} 3.6 \mathrm{H} 2 \mathrm{O}(10: 1: 1)$ shake then incubated for $30 \mathrm{~min}$ at $37^{\circ} \mathrm{C}$. The mixture read at $593 \mathrm{~nm}$. Methanol was used to replace the sample as a control. The plate blank contains methanol $300 \mu$ l. The standard curve uses AFS. This method refers to the research of Pereira et al. ${ }^{11}$ and Wong et al. ${ }^{12}$

The method done with Microplate Reader. AFS used as a standard solution and stocked with various concentration (1200; 600; 300; 150; 75 ; and $37.5 \mu \mathrm{M})$. The antioxidant activity was calculate according to Wong et al.

FeEAC $=\frac{\triangle A}{G R A D} \times \frac{A v}{S p v} \times \mathrm{D} \times \frac{1}{\operatorname{cext}} \times 10^{5}$

Based on the formula, FeEAC was the equality of ferric ions with antioxidant activity $(\mu \mathrm{mol} / \mathrm{g})$, which $\Delta \mathrm{A}=$ absorbance of samples that have been reduced by blank, GRAD $\left(\mathrm{M}^{-1}\right)$ was the gradient of the AFS calibration graph, $\mathrm{Av}=$ total volume for the test $(300 \mu \mathrm{l}), \mathrm{Spv}=$ sample volume $(30 \mu \mathrm{l}), \mathrm{C}_{\text {ext }}=$ concentration of sample stock, weight (gram) in volume $(\mathrm{g} / \mathrm{l}), \mathrm{D}=$ dilution factor for sample before analysis $(\mathrm{D}=1$ if sample not diluted). GRAD (gradient) determined from the calibration curve on AFS.

\section{Determined the total phenols content (TPC)}

TPC expressed as mg Gallic acid equivalents per gram of dried extract (mg GAE/g extract). A total of $20 \mu$ l extract added with $100 \mu$ l of Folin-C Reagent (1:10), treated for 60 seconds, and then allowed to stand for 4 min. Added with $80 \mu \mathrm{l}$ of solution of $7.5 \%$ sodium carbonate $\left(\mathrm{Na}_{2} \mathrm{CO}_{3}\right)$ in water, shake for 60 seconds. This mixture is incubated at room temperature in a dark place for $2 \mathrm{~h}$. Read at $600 \mathrm{~nm}$. The concentration of extract in the sample made at $100 \mu \mathrm{g} / \mathrm{ml}$. The concentration of stock solution made was $1000 \mu \mathrm{g} / \mathrm{ml}$. The control was a sample replaced with methanol. The treatment was the same as the sample. The total phenols content using gallic acid as standards. TPC calculated as the equivalence of gallic acid (mg GAE / gram). This method according to Farasat. ${ }^{13}$

\section{Total flavonoids content (TFC)}

The total flavonoids content determined by the method described by Farasat et al. with slight modification. The extract $(20 \mu \mathrm{l})$ in methanol added to $20 \mu \mathrm{l}$ of $\mathrm{AlCl}_{3} .6 \mathrm{H}_{2} \mathrm{O} 10 \%$ and $20 \mu \mathrm{l}$ of $1 \mathrm{M}$ potassium acetate and $180 \mu \mathrm{l}$ of distilled water, and left at room temperature for $30 \mathrm{~min}$. The solution properly mixed, and the color intensity of the mixture read at $415 \mathrm{~nm}$ after $15 \mathrm{~min}$. Quercetin used as the standard. All experiments done in triplicate.

\section{Phytochemical screening}

The extract determined the chemical compounds and the procedure according to Indonesian Herb Pharmacopoeia and Harbone. ${ }^{14,15}$ The chemical constituent identification were alkaloids, flavonoids, tannins, saponins, anthraquinones.

\section{Nephroprotective activity}

Nephroprotective activity used six groups, consists of positive control with quercetin dose $50 \mathrm{mg} / \mathrm{kg}$ orally; negative control was given $0.5 \%$ Na.CMC, normal control given standard feed and $0.5 \% \mathrm{Na.CMC}$, The extract dose $50 \mathrm{mg} / \mathrm{kg}, 100 \mathrm{mg} / \mathrm{kg}$ and $200 \mathrm{mg} / \mathrm{kg}$. The experimental animals used were Wistar strain rats weighing 200-250 grams, male. The rats acclimatized for seven days, then the next seven days were given extract/quercetin/Na.CMC according to the group. The last day, after 2 hours of oral extract, mice were induced by gentamicin at a dose $80 \mathrm{mg} / \mathrm{kg}$ intra peritoneal. Induced by gentamicin for all the groups except normal control. After 24 hours, the rats anesthetized with ketamine $230 \mathrm{mg} / \mathrm{kg}$. The blood of rats was carry out and also isolate their kidney organs. The parameters of nephroprotective activity are serum creatinine, urea and histology observed such as casts in tubules, necrosis of tubules, and glomerular swelling. The parameters observations of descriptive casts on the tubules and damage of the tubules. The glomerular swelling calculated by measuring the distance farthest from the edge of the Bowman capsule to the glomerular edge. The tubular damage, calculated using $=(\mathrm{n} / \mathrm{m} \times 100 \%)$, where $\mathrm{n}$ is the number of proximal tubules that have closed in one field of view and $\mathrm{m}$ is the sum of all proximal tubules in one field of view. Then the results are averaged to obtain a percentage damage of kidney in each rat . This study was permitted by Ethic committee with number KEPKUHAMKA 02/19.06/44.

\section{RESULTS AND DISCUSSION}

\section{Antioxidant activity with DPPH method}

The antioxidant activity test was performed using DPPH and FRAP. The following results obtained. The $\mathrm{IC}_{50}$ was $162.34 \mu \mathrm{g} / \mathrm{ml}$. Quercetine as a positive control was $5.63 \mu \mathrm{g} / \mathrm{ml}$. The result of antioxidant activity by DPPH method on the Figure 1.

\section{Antioxidant activity with FRAP methods}

The antioxidant activity test was performed using FRAP. The extract has antioxidant activity 18,65 $\pm 3,53 \mathrm{FeEAC}(\mathrm{mol} / \mathrm{g})$ and the positive control (quercetine) 1201,61 $\pm 77,89 \mathrm{FeEAC}(\mathrm{mol} / \mathrm{g})$. The result of antioxidant activity on the Figure 2.

\section{Determination of total phenols and total flavonoids}

Quercetin levels calculated as total flavonoid levels in the sample. Gallic acid levels calculated as total phenols levels in the sample. The result showed on Table 1. The total phenols in the extract was high than the flavonoids.

\section{Phytochemical screening}

The flavonoids, glycosides, alkaloids, tannins, terpenes, and saponins were presence in the extract and negative to anthraquinone. The test results showed in Table 2.

\section{Nephroprotective activity}

\section{Creatine serum}

Serum creatinine showed the result that a dose of $200 \mathrm{mg} / \mathrm{kg}$ showed the lowest creatinine level. The results of the average levels of each group showed in the Figure 3.

The normality test is carried out with the Kolmogorov-Smirnov test, the Sig. $>0.05$, creatinine data normally distributed. The Levene test results Sig. 0.498 ( $\mathrm{p}>0.05$ ), its means that the creatinine data homogeny. One Way Anova statistical analysis test shows the value of sig. 0,000 ( $\mathrm{p}<0.05$ ). There were significant differences between treatment groups for creatinin. Post Hoc ANOVA test by Tukey. The result show that all doses had activity as nephroprotective which seen from the existence of 


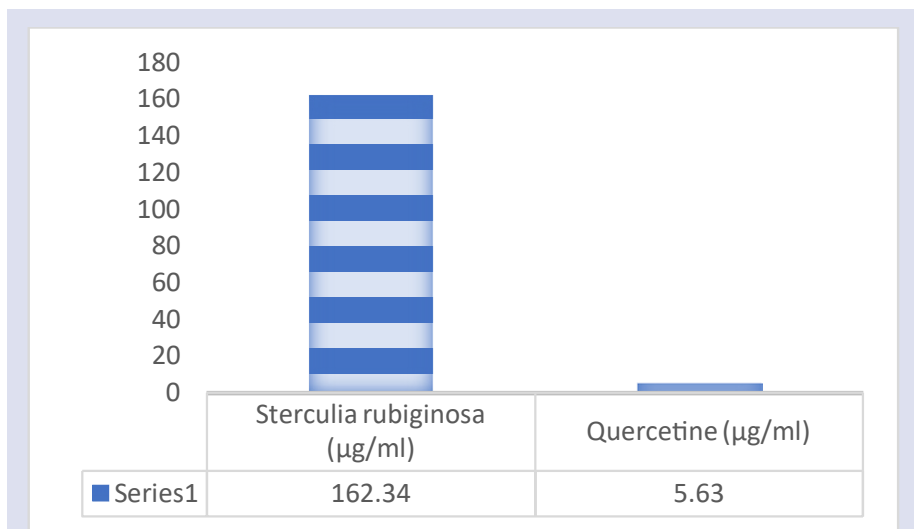

Figure 1: Antioxidant activities of extract S.rubiginosa leaves by DPPH methods.

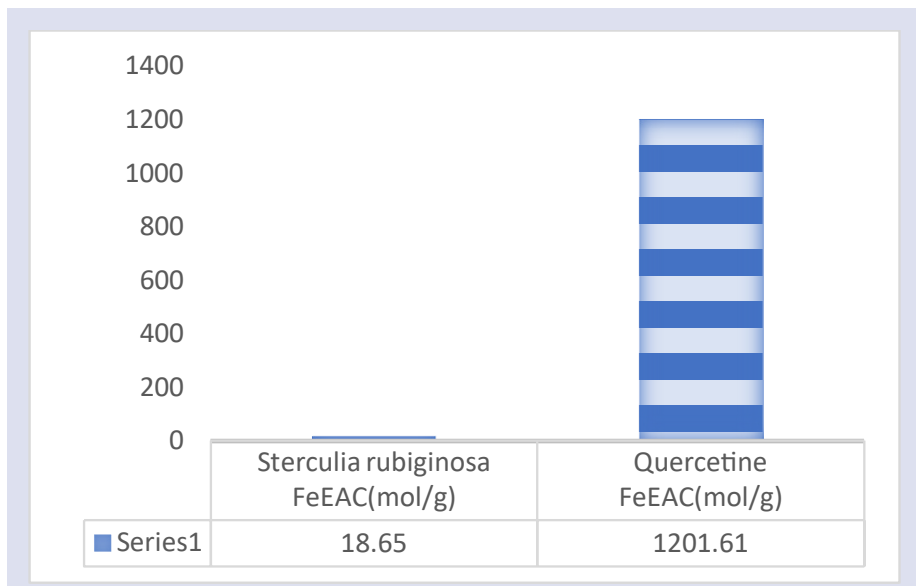

Figure 2: Antioxidant activities of extract S.rubiginosa leaves by FRAP methods.

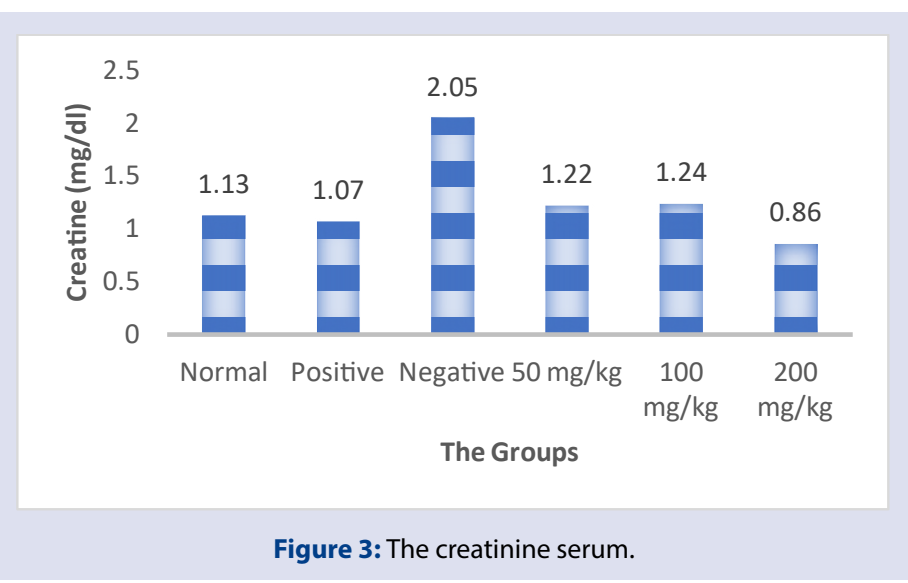

Table 1: Total phenols and total flavonoids.

\begin{tabular}{cccc}
\hline Parameters & Content & Sd & kV \\
\hline Total Phenols & $462,36 \mathrm{GAE} / \mathrm{g}$ extract & 9,23 & 1,99 \\
Total Flavonoids & $59,44 \mathrm{QE} / \mathrm{g}$ extract & 0,11 & 0,96 \\
\hline
\end{tabular}


Table 2: The chemical content of extract S. rubiginosa.

\begin{tabular}{cc}
\hline Chemical constituents & Result \\
\hline Alkaloids & + \\
Flavonoids & + \\
Terpenes & + \\
Tannins & + \\
Glycosides & + \\
Anthraquinones & - \\
\hline
\end{tabular}

Note: $+=$ Presence, $-=$ Absence

significant differences with negative controls. Doses $200 \mathrm{mg} / \mathrm{kg}$ did not show significant differences with positive control, which means that the ability as a nephroprotective was the same as positive control. Whereas for dosages 50 and $100 \mathrm{mg} / \mathrm{kg}$ also showed no significant difference with positive control, but showed a significant difference with a dose of $200 \mathrm{mg} / \mathrm{kg}$.

\section{Urea serum}

Urea serum showed that a dose of $50 \mathrm{mg} / \mathrm{kg}$ has the lowest creatinine level. The results of the average levels of each group showed in the figure 4.

The normality test carried out with the Kolmogorov-Smirnov test and the Sig. $>0.05$ ( $p>0.05)$. The Urea levels normally distributed. The Levene, the significant 0.124 ( $p>0.05$ ), the data homogeneously distributed. One way ANOVA statistical analysis test shows there is a significant difference between treatment groups on urea. Post hoc use Tukey analyze. The results showed that all doses have nephroprotective activity as seen from the existence of significant differences with negative controls. The dose $50 \mathrm{mg} / \mathrm{kg}$ did not show a significant difference with positive control, which means that the ability as a nephroprotective was the same as positive control whereas the highest dose of $200 \mathrm{mg} / \mathrm{kg}$ shows a decrease in activity as a nephroprotective.

\section{Histopathology}

The kidney structure observed the distance between the bowman capsule and glomerulus, tubular necrosis and the presence of casts. According to the results of research Pragati et al. ${ }^{16}$ Kidney damage caused by administration of gentamicin, one of which is the formation of casts, casts are a collection of proteins that result in inhibited channeling through renal tubules, also stimulates the occurrence of necrosis in the tubules. The results showed in Figure 5, the casts are in the negative control. In treatments except normal control, founded changes in the form of proximal tubule.

\section{Necrosis tubules}

The results of the calculation of tubular necrosis showed in figure 5 .

The statistical test results show that the data not homogeneously distributed The test conducted with non-parametric analysis Mann Whitney. The results of the non-parametric analysis showed on Table 3.

The distance between glomerulus and bowman capsules

Kidney is one of the organs filled with blood vessels. If endothelial cells in blood vessels have been damaged by free radicals, then the possibility of kidney function will decrease. An imbalance in the amount of free radicals and antioxidants causes oxidative stress which causes atrophy in the glomerulus and proximal tubular necrosis. ${ }^{17}$ In this study atrophy of the glomerulus was observed by measuring the distance between the bowman capsule and the glomerulus. Based on observations of the distance between bowman capsules and renal glomerulus of rats induced by gentamicin can be seen in the graph below (Figure 7):
Nephrotoxicity due to gentamicin occurs through the mechanism of leukocytosis, necrosis, ROS, and infiltration of inflammatory cells. ${ }^{18}$ The accumulation of gentamicin in the kidneys, especially in proximal tubular cells, can cause oxidative stress, resulting in excessive ROS. The ROS can cause oxidative damage to mitochondria and plasma membranes, increased creatinine, urea, and uric acid may be related to loss of glomerular filtration, mesangial cell proliferation, and apoptosis induced by gentamicin. In our study, gentamicin caused kidney dysfunction, this marked by increased levels of creatinine, urea, and this similar with previous studies. ${ }^{16,19,2,20,21}$ In this study, administration of Sterculia rubiginosa leaf extract significantly reduced creatinine, urea and kidney tissue damage levels. The antioxidant activity of Sterculia rubiginosa leaf extract was carried out in vitro by the FRAP and DPPH methods. The FRAP test was based on the ability of the phenol to reduce the yellow color of ferric tripyridyltriazine ( $\mathrm{Fe}$ (III) -TPTZ) to the blue color of the ferro (Fe (II) -TPTZ complex) by antioxidant activity that contributes to electrons. The blue color produced was measured spectrophotometrically at 593. Ferric salt was used as an oxidant and its redox potential $(<0.70 \mathrm{~V})$, the FRAP. ${ }^{22}$ The test required an acidic condition (non-physiological, mol of Fe (III) to Fe (II)). Previous studies conducted by previous researchers learned that treatment with medicinal plant antioxidants significantly prevented elevated creatinine levels and gentamicin-induced kidney damage. And the results obtained that phenolic compounds, flavonoids have antioxidant activity that is possibly responsible for the activity of nephroprotectors. ${ }^{18,23}$

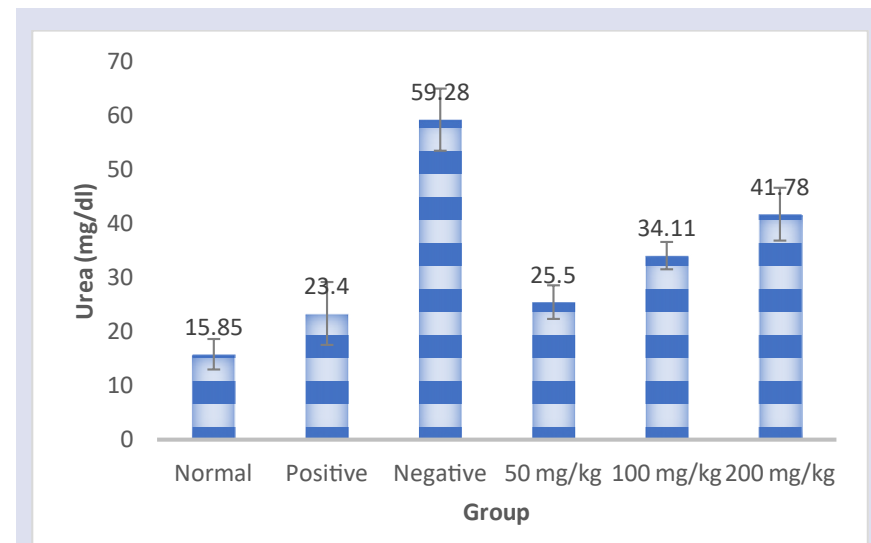

Figure 4: The urea serum.

Table 3: The non-parametric analysis of tubulus necrosis.

\begin{tabular}{ccc}
\hline Groups & Groups & Sig. \\
\hline Normal & Positive* &, 020 \\
& Negative* &, 021 \\
& $50 \mathrm{mg} / \mathrm{kg}^{*}$ &, 021 \\
& $100 \mathrm{mg} / \mathrm{kg}^{*}$ &, 043 \\
& $200 \mathrm{mg} / \mathrm{kg}^{*}$ &, 021 \\
& Negative mg/kg* &, 020 \\
Positif & $50 \mathrm{mg} / \mathrm{kg}^{*}$ &, 020 \\
& $100 \mathrm{mg} / \mathrm{kg}^{*}$ & 1,000 \\
& $200 \mathrm{mg} / \mathrm{kg}^{*}$ &, 020 \\
& $50 \mathrm{mg} / \mathrm{kg}^{*}$ &, 564 \\
Negatif & $100 \mathrm{mg} / \mathrm{kg}^{*}$ &, 021 \\
& $200 \mathrm{mg} / \mathrm{kg}^{*}$ &, 021 \\
& $100 \mathrm{mg} / \mathrm{kg}^{*}$ &, 021 \\
$50 \mathrm{mg}$ & $200 \mathrm{mg} / \mathrm{kg}^{*}$ &, 021 \\
& $200 \mathrm{mg} / \mathrm{kg}^{*}$ &, 021 \\
\hline \multirow{2}{*}{$100 \mathrm{mg}$} &
\end{tabular}

* = significant differences 


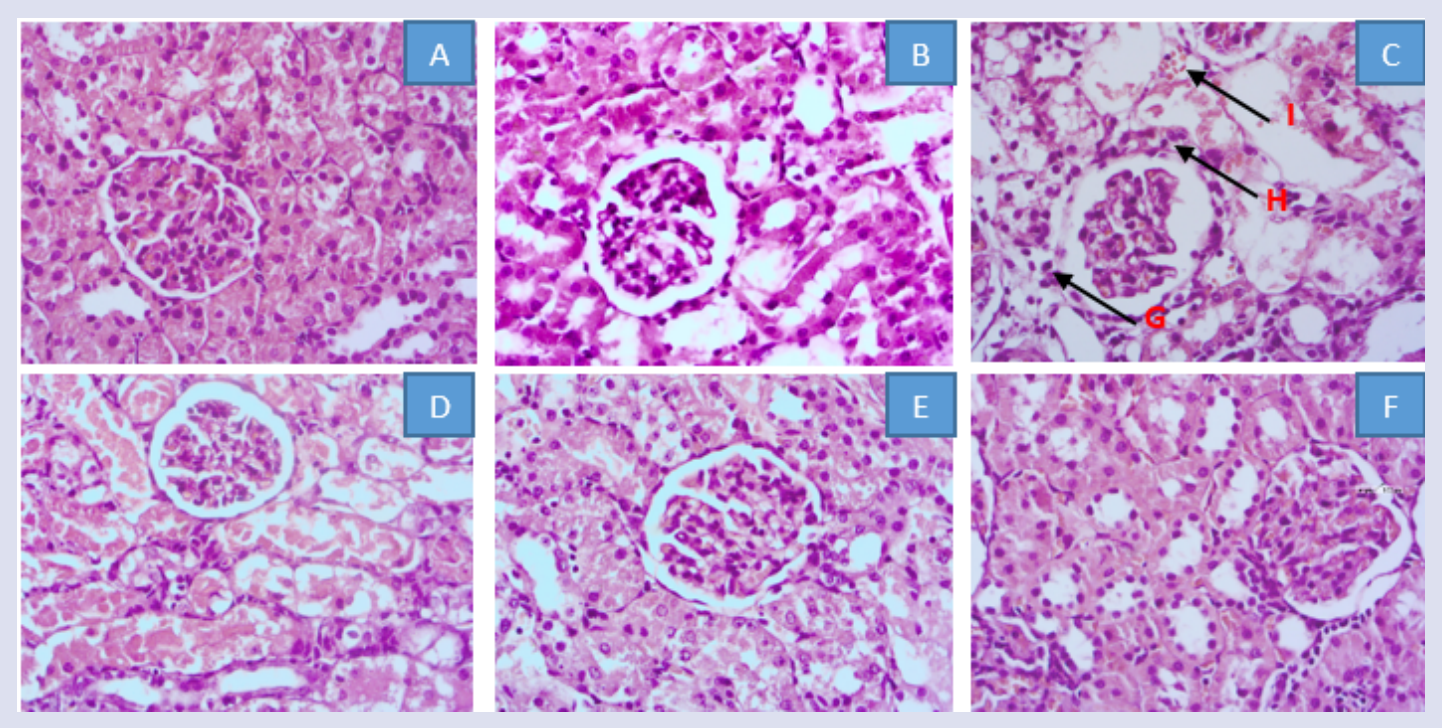

Figure 5: Histopathology kidney (A)Normal control, (B) Positive control, (C)Negative control, (D) dose $50 \mathrm{mg} / \mathrm{kg}$, (E) Dose $100 \mathrm{mg} / \mathrm{kg}$, (F) dose $200 \mathrm{mg} / \mathrm{kg}$, (G) Necrosis cell, (H) Narrowing / closing proximal tubules, (I) Casts.
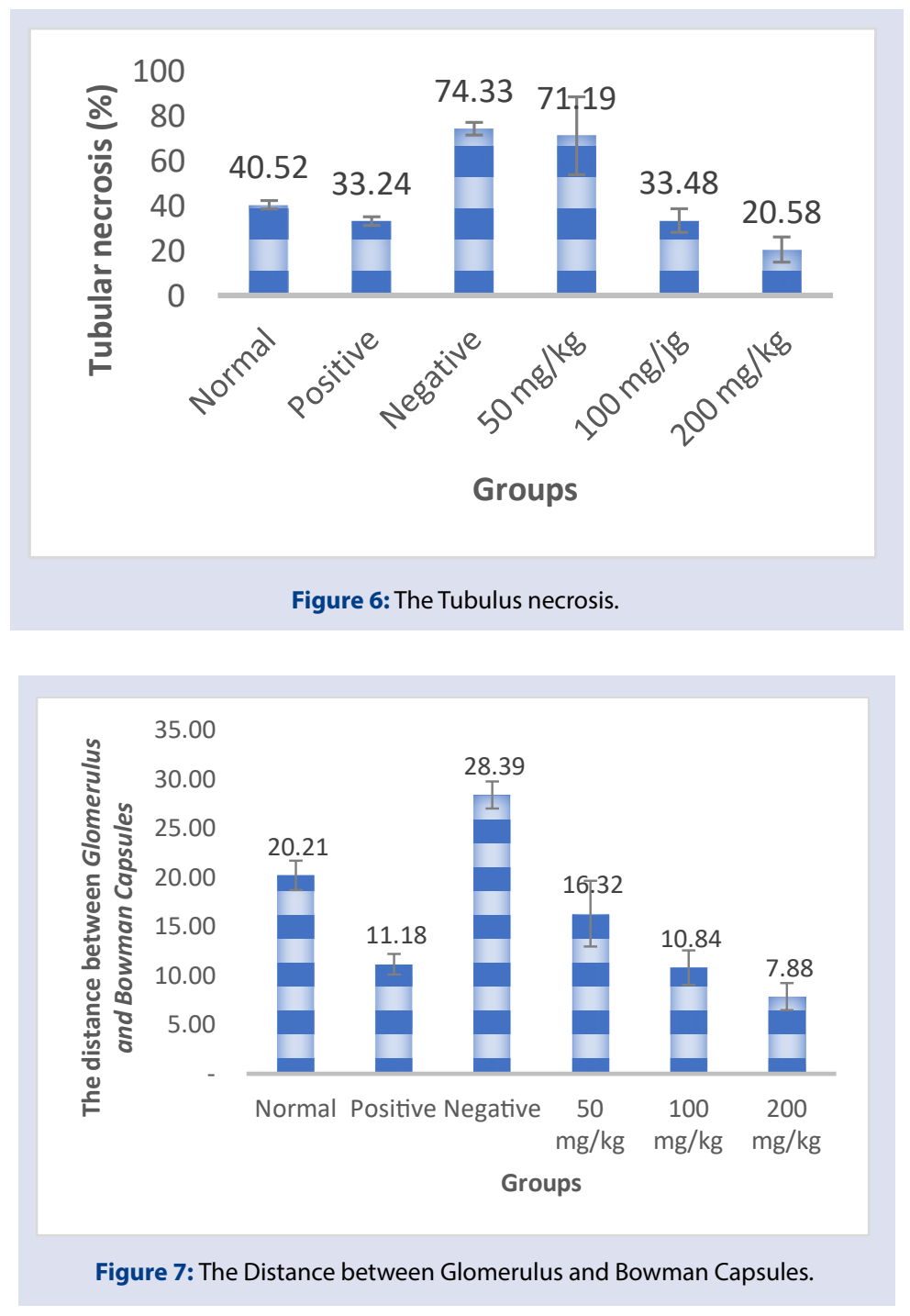


\section{CONCLUSION}

The ethanol extract of Sterculia rubiginosa has nephroprotective and antioxidant activity. This extract potential to continue for another research to find the most active chemical constituent who is responsible to this activity.

\section{ETHICAL ISSUES}

This study was permitted by Ethic committee with number KEPKUHAMKA 02/19.06/44.

\section{CONFLICTS OF INTEREST}

All the authors declare there is no conflicts of interest.

\section{ACKNOWLEDGEMENT}

The authors are grateful to The Ministry of Research, Technology and Higher Education, The Government of Indonesia Republic for Research Foundation via Hibah PDUPT.

\section{REFERENCES}

1. N. Tlili, A. Feriani, E. Saadoui, N. Nasri, and A. Khaldi. Capparis spinosa leaves extract : Source of bioantioxidants with nephroprotective and hepatoprotective effects. Biomed Pharmacother. 2017;87:71-179.

2. M. Veljkovi, D. R. Pavlovi, N. Stojiljkovi, S. Ili, I. Jovanovi, V. Raki, and L. Veli. Bilberry: Chemical Profiling, in Vitro and in Vivo Antioxidant Activity and Nephroprotective Effect against Gentamicin Toxicity in Rats. Phytoterapi Research. 2016;1-12.

3. S. N. A. Saleh, M el, Alia Yassin, Kaseem Mona el said, Marzouk mona mohammad, Mosharafa salwa ali. Phytochemstry, biological activities and economical uses of the genus Sterculia and the related genera: A review. Asian Pacific J Trop Dis. 2016;6:6:492-501.

4. A. A. Braga and R. Rodrigues, Gracy, Gregorio, Hilzet, et al. Antibacterial and Hemolytic Activity of a new Lectin Purified from the Seeds of Sterculia Foetida L. Appl Biochem Biotechnol. 2015;175:1689-99.

5. A. Jafri, S. Bano, J. Rais, F. Khan, and N. Shivnath. Phytochemical screening of Sterculia foetida seed extract for anti-oxidant, anti-microbial activity, and detection of apoptosis through reactive oxygen species (ROS) generation, mitochondrial membrane potential (MMP) decrease, and nuclear fragmentation in human osteosarcoma cells. J Histotechnol. 2019;1-12.

6. A. N. and I. U. Fazle Rabbi, Amir Zada, Achyut Adhikari, Almas Jabeen. Sterculia diversifolia bears anti-cancer and immunomodulatory activities. Bangladesh $\mathrm{J}$ Pharmacol. 2017;12;52-5.

7. Z. Uddin, T. Bin Emran, A. K. Nath, I. Hossain, M. Alamgir, and S. Rana. In vitro Antioxidative, Fibrinolytic and Phytochemical Effects of Different Extracts of Sterculia villosa Barks. Int J Res Pharm Biosci. 2015;2;1:1-9.
8. F. Hossain, B. Talukder, M. N. Rana, R. Tasnim, T. S. Nipun, S. M. N. Uddin, and S. M. M. Hossen. In vivo sedative activity of methanolic extract of Sterculia villosa Roxb . leaves. BMC Complement. Altern. Med. 2016;16:10-13.

9. O. M. Mogbojuri, A. A. Adedapo, and M. O. Abatan. Phytochemical screening safety evaluation, anti-inflammatory and analgesic studies of the leaf extracts of Sterculia tragacantha. J Complement Integr Med. 2016;2-7.

10. G. Bobo-garcía, G. Davidov-pardo, C. Arroqui, and M. R. Marín-arroyo. Intralaboratory validation of microplate methods for total phenolic content and antioxidant activity on polyphenolic extracts, and comparison with conventional spectrophotometric methods. J Sci Food Agric. 2015;95;204-9.

11. J. A. Figueira, J. A. M. Pereira, P. Porto-figueira, and J. S. Câmara. Analysis Ultrasound-assisted liquid-liquid extraction followed by ultrahigh pressure liquid chromatography for the quanti fi cation of major carotenoids in tomato. J Food Compos Anal. 2017;57:87-93

12. Wong. Cw, C. Wsm, L. Yy, B. De, andT. Aas. A FRAP Assay at $\mathrm{pH} 7$ unveils Extra Antioxidant Activity from Green, Black, White and Rooibos Tea but not Apple Tea. Food Nutr Rep. 2015;1(1):1-8.

13. M. Farasat and R. Khavari-nejad. Antioxidant Activity, Total Phenolics and Flavonoid Contents of some Edible Green Seaweeds from Northern Coasts of the Persian Gulf. Iran. J Pharm Res. 2014;13(1):163-70.

14. Anonymous., Farmakope Herbal Indonesia. Ed I., Departemen Kesehatan Republik Indonesia (Department of Health of RI) Jakarta, Indonesia. 2008.

15. J. Harborne, A Guide to Modern Techniques of Plant Analysis. Phytochemical Methods. Chapman and Hall London. 1998.

16. P. Srivastava, R. R. R, P. J. Shenoy, P. A. Manjrekar, S. Teerthanath, and S Bhuvaneshwari. Nephroprotective Effect of Anethum graveolens in a Murine Model of Gentamicin induced Nephrotoxicity. 2018;10(2):155-8.

17. H. M. Galal and N. M. Abd. Aqueous garlic extract supresses experimental gentamicin induced renal pathophysiology mediated by oxidative stress, inflammation and Kim-1. Pathophysiology. 2019;1-9.

18. E. Heidarian, E. Jafari-dehkordi, and P. Valipour, Nephroprotective and AntiInflammatory Effects of Pistacia atlantica Leaf Hydroethanolic Extract Against Gentamicin-Induced Nephrotoxicity in Rats Nephroprotective and AntiInflammatory Effects of Pistacia atlantica Leaf Hydroethanolic Extract Against Gen. J Diet Suppl. 2017;1-14.

19. S. Shiyan and L. R. Sari. Nephroprotective of Anthocyanin Pigments Extract From Red Cabbage (Brassica olearacea L. var Capitata F.Rubra) against Gentamicin-captopril Induced Nephrotoxicity in Rats. 2018;11( 4):432436.

20. B. Abdullah, D. M. El-nagar, and K. Elfakki. Reno-protective effects of propolis on gentamicin-induced acute renal toxicity in swiss albino mice. 2016;6:643-652.

21. N. Aiswarya, R.V., Chandran, S. Teerthanath, P. Rakesh, R. Rashmi, and J. Preethi. Nephroprotective Effect of Aqueous Extract of Pimpinella anisum in Gentamicin Induced Nephrotoxicity in Wistar Rats. 2018;10(3):403-7.

22. A. Karadag, B. Ozcelik, and S. Saner. Review of Methods to Determine Antioxidant Capacities. Food Anal. Methods. 2009;2(41):41-60.

23. N. Nerdy and K. Ritarwan. Hepatoprotective Activity and Nephroprotective Activity of Peel Extract from Three Varieties of the Passion Fruit (Passiflora Sp.) in the Albino Rat. 2019;7;4:536-42. 


\section{GRAPHICAL ABSTRACT}

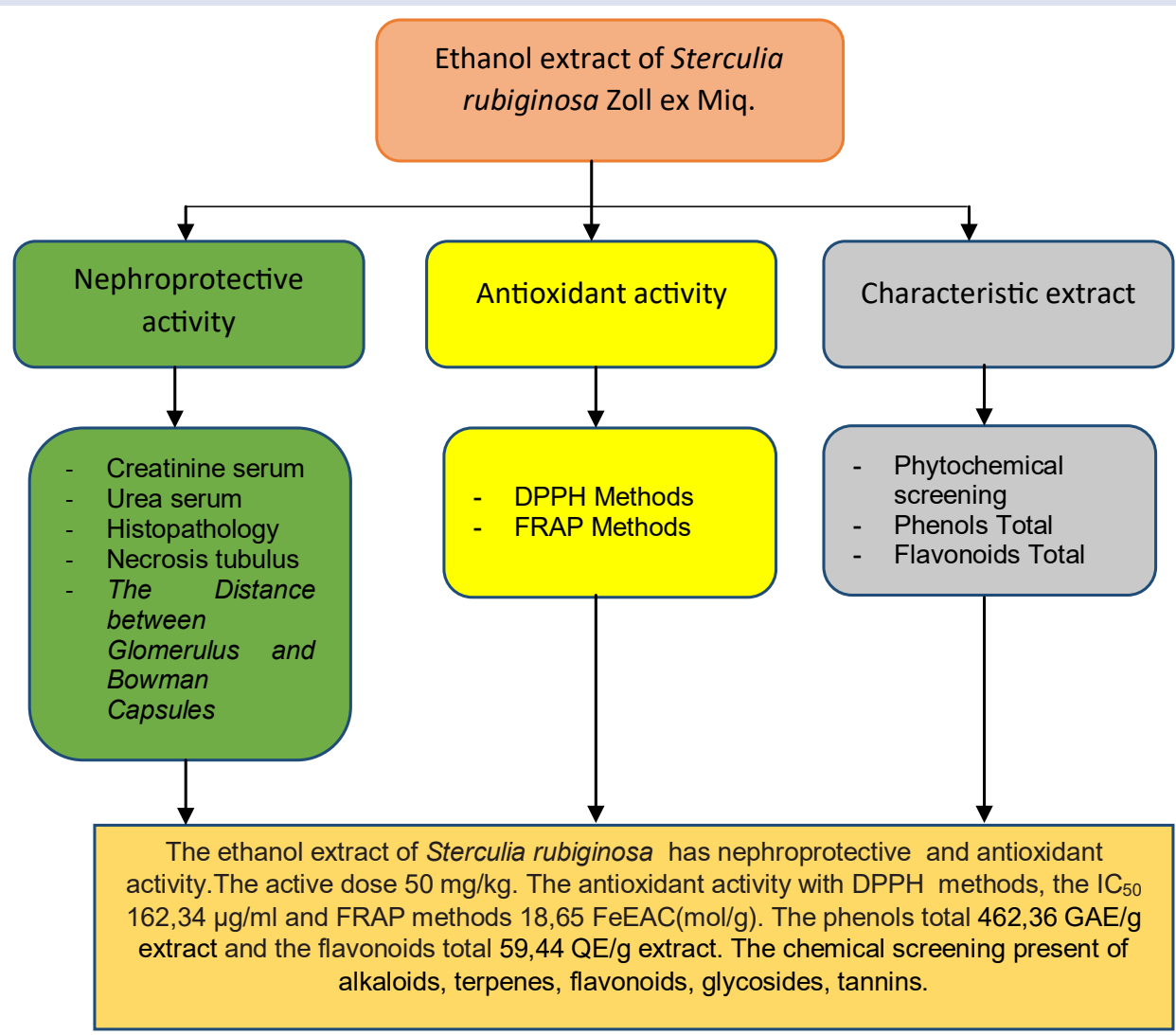

Cite this article: Prastiwi R, Dewanti E, Fadliani IN, Aqilla N, Salsabila S, Ladeska V. The Nephroprotective And Antioxidant Activity of Sterculia rubiginosa Zoll. Ex Miq. Leaves. Pharmacogn J. 2020;12(4):843-9. 